\title{
Zoologischer Anzeiger
}

\section{Morphology of the male reproductive system during post-embryonic development of the termite Silvestritermes euamignathus (Isoptera: Termitidae)}

\author{
Lara Teixeira Laranjo $^{\mathrm{a}}$, Ives Haifig ${ }^{\mathrm{b}}$, Ana Maria Costa-Leonardo ${ }^{\mathrm{a}, *}$ \\ a Laboratório de Cupins, Departamento de Biologia, Instituto de Biociências, Univ Estadual Paulista, UNESP, Campus Rio Claro, Avenida 24A, 1515, Bela \\ Vista, Rio Claro, SP 13506-900, Brazil \\ b Instituto de Ciências Agrárias, Universidade Federal de Uberlândia, UFU, Campus Monte Carmelo, Rodovia LMG 746, km 01, Monte Carmelo, MG \\ 38500-000, Brazil
}

\section{A R T I C L E I N F O}

\section{Article history:}

Received 28 March 2017

Received in revised form

28 November 2017

Accepted 28 November 2017

Available online 5 December 2017

Corresponding Editor: Sven Bradler

\section{Keywords:}

Histochemistry

Reproductive system

Seminal vesicles

Testicles

Vas deferens

\begin{abstract}
A B S T R A C T
Despite the recent research on Isoptera reproduction strategies, few studies have focused on the morphophysiology of the reproductive system in Neotropical termite species. The classic literature emphasizes the development of the female reproductive apparatus, generating a knowledge gap on the male reproductive system, including its neotenic differentiation and the evolution of the seminal vesicles. The development of the reproductive system in males of Silvestritermes euamignathus was followed from firstinstar nymphs until primary kings, with emphasis on the histology of the gonads and seminal vesicles of primary and neotenic kings from field colonies. The maturation of the reproductive system follows post-embryonic development, reaching a peak of development in primary functional kings from field colonies. The testicles are already present in first-instar nymphs and show a progressive development that is completed in primary kings, which are characterized by an enlarged size and greater sperm production. Although spermatogenesis is observed in third-instar nymphs, only in fifth-instar nymphs are spermatozoa present in the testicles and in the seminal vesicles. Spermatozoa are also present in the testicles of neotenic reproductives, derived from different nymphal instars. After the foundation of a new colony and the maturation of the king, there is a significant increase in the reproductive apparatus and the testicular lobes, which mostly occupy the whole posterior abdomen in kings from field colonies. These individuals have a minimum of seven testicular lobes that are completely separated from each other and contain rounded, aflagellated spermatozoa, which are approximately $2-3 \mu \mathrm{m}$ in diameter. Four-month old kings from laboratory colonies seem to be in a period of reproductive pause, as they display fewer sperm in the seminal vesicles. The seminal vesicles are specialized portions of the vasa deferentia that play a role in storage of spermatozoa. These structures produce a proteinaceous secretion in alates that is not observed in kings. The overall results indicate early maturation of the reproductive system in males of $S$. euamignathus; furthermore, the reproductive status of the different individuals might be linked to the development of the testicles and the production, storage and release of spermatozoa. The lack of a proteinaceous secretion in the seminal vesicles of kings, in comparison to alates, might be related to the maturation of the individuals after colony establishment. The development of the male reproductive system is consistent with queen physogastry, but in more discreet proportions.
\end{abstract}

(c) 2017 Elsevier GmbH. All rights reserved.

\section{Introduction}

The infraorder Isoptera comprises over 2900 species of termites worldwide, covering nine families according to the classification by Krishna et al. (2013). Approximately 600 termite species are distributed into five families in the Neotropical region, with Termi-

\footnotetext{
* Corresponding author.

E-mail address: amcl@rc.unesp.br (A.M. Costa-Leonardo).
}

tidae as the dominant family, having more than 420 species in the Neotropics (Constantino, 2017).

The caste system of Termitidae follows a bifurcated pattern, and post-embryonic development can follow one of two lines. In the first line, a first-instar larva emerges from the egg and molts into a second-instar larva that will become either a worker or a presoldier, which will later become a soldier. The individuals that follow this pathway belong to the apterous lineage. In the second line, the first-instar larva molts into a first-instar nymph, which will have successive molting events until become an imago or alate. These 
individuals, the imago and its predecessors, belong to the imaginal lineage (Noirot, 1969; Roisin, 2000).

Caste differentiation occurs during ontogenetic development and may be influenced by both environmental (Mao and Henderson, 2007) and genetic factors (Hayashi et al., 2007; Matsuura et al., 2009; Kitade et al., 2011). Sometimes, the individuals deviate from their differentiation pathway and generate the so-called neotenic reproductives (Myles, 1999). This occurs either due to changes in the environment, e.g. when the colonies are orphaned (Costa-Leonardo and Barsotti, 1998), or by genetic influences, e.g. asexual queen succession through parthenogenesis (Matsuura et al., 2009; Vargo et al., 2012; Luchetti et al., 2013; Fougeyrollas et al., 2015; Fournier et al., 2016; Matsuura 2017; Fougeyrollas et al., 2017; Hellemans et al., 2017). Neotenic termites may originate from either nymphs or workers, being respectively called nymphoids and ergatoids (Myles, 1999).

Many nymphoid neotenics of both sexes have been widely described in nests of Silvestritermes euamignathus (Noirot, 1956; Araújo, 1958; Noirot, 1969; Grassé, 1982; Costa-Leonardo et al., 1996, 1998, 1999; Haifig et al., 2016). This termite species is characterized by building epigeal mounds, very common in Cerrado vegetation (Mathews, 1977; Domingos, 1985). According to Haifig and Costa-Leonardo (2016), the imaginal line of S. euamignathus presents one larval and five successive nymphal instars during its post-embryonic development, with nymphoids differentiating from the last three nymphal instars. The neotenics from the same colony may present different morphologies: females with various degrees of physogastry and males with different wing bud sizes and body pigmentation (Costa-Leonardo et al., 1999; Haifig et al., 2016).

The reproductive biology of termites has been widely studied over the last years, as the reproductive mechanism is one of the factors that define the relationships among the castes of a single colony (Hartke and Baer, 2011). On the other hand, the physiological details involved in the production, transference and storage of spermatozoa in termites have received little attention (Dean and Gold, 2004; Ye et al., 2009). The king remains with the queen, and mating occurs intermittently, with oviposition cycles in some species (Raina et al., 2007). According to Hartke and Baer (2011), the ability of termite kings to supply large quantities of viable spermatozoa to the queen, throughout decades, is as important as the fact that some female hymenopterans are capable of storing spermatozoa from their deceased partners for a similar period of time. However, the study of the reproductive system in kings has been neglected when compared to that of queens.

Herein, this study focused on a detailed morphological analysis of the gonads in males of imaginal line, throughout post-embryonic development and its deviations into neotenics, aiming to understand the role of different functional males of S. euamignathus in reproduction.

\section{Materials and methods}

2.1 Termites: In this study, the following males of Silvestritermes euamignathus (Silvestri, 1901) were used: alates (collected during swarming); four-month old primary kings (collected from laboratory colonies); primary and nymphoid neotenic kings from field nests. Nymphs of this species were collected directly from nests and classified into five instars (N1 to N5), according to the morphometric analyses performed by Haifig and Costa-Leonardo (2016). The neotenic kings were collected from a field nest headed by 31 females and 29 males and lacking the primary royal couple. The neotenic kings and queens were active in reproduction (functional) because eggs were found in the nest. At least three nymphs of each instar were used for histology, and several alates and kings of dif- ferent ages were used for dissection $(n=21)$, for histology $(n=7)$ and for TEM $(\mathrm{n}=3)$.

2.2 Anatomy of the reproductive system: Twenty-one male alates of $S$. euamignathus were dissected in a saline solution for insects ( $\left.0.1 \mathrm{M} \mathrm{NaCl}, 0.1 \mathrm{M} \mathrm{Na}_{2} \mathrm{HPO}_{4}, 0.1 \mathrm{M} \mathrm{KH}_{2} \mathrm{PO}_{4}\right)$, and reproductive organs were isolated under a stereomicroscope. These organs were individually placed on a microscope slide, stained with $1 \%$ methylene blue solution, and imaged with the aid of Motic-CAM (Causeway Bay, Hong Kong) camera. Measurements of the length and width of the vas deferens and seminal vesicles were obtained using Motic Image Plus 2.0 ML software.

2.3 Histology and histochemistry: The final abdominal portion of male nymphs of five different instars (N1-N5), male alates, four-month old kings from laboratory colonies and primary and neotenic kings from field colonies of $S$. euamignathus were fixed in FAA (absolute alcohol, acetic acid and formaldehyde, 3:1:1) for approximately $24 \mathrm{~h}$. Later, they were dehydrated in a graded series of ethanol concentrations (70-95\%) and transferred to an infiltration resin solution (Leica ${ }^{\circledR}$ ). The samples were embedded laterally with Historesin $\left(\right.$ Leica $^{\circledR}$ ) plus catalyzer for polymerization, and $3 \mu \mathrm{m}$ sections were prepared using a Leica RM2245 microtome. The sections were stained with hematoxylin-eosin and observed under a photomicroscope (Leica DM500/Leica ICC50). Sections of the abdomens of alates and kings were also stained with PAS and xylidine-Ponceau for detection of polysaccharides and total proteins, respectively. Images were recorded with the aid of LAS v4.0 software (Leica Application Suite v4). A quantitative analysis of the testicular area using the five most sagittal sections of the testicles, certified by the lumen of the vas deferens, from different individuals was performed using Image J 1.50i software. Data were logarithmically transformed to achieve both normality and homoscedasticity (Crawley 2007), and analyzed using one-way ANOVA followed by Tukey HSD for multiple comparisons. The analyses were performed in the R program, version 3.3.1 ( $\mathrm{R}$ Core Team 2016).

2.4 Transmission Electron Microscopy (TEM): The abdomens of male alates were fixed in $2.5 \%$ glutaraldehyde, post-fixed in $1 \%$ $\mathrm{OsO}_{4}$, and embedded in Araldite epon resin. The samples were embedded in pure Epon resin and polymerized at $60^{\circ} \mathrm{C}$ for $72 \mathrm{~h}$. Ultrathin sections (60-90 nm) were obtained using a Leica Reichert Supernova ultramicrotome and contrasted with uranyl acetate $4 \%$ and lead citrate. The material was observed under a Philips CM100 transmission electron microscope (operating at an accelerating voltage of $80 \mathrm{kV}$ ) and photographed with a Veleta camera using iTEM software (v. 5.2).

\section{Results}

The reproductive system of males of $S$. euamignathus consists of two testicles, from which arise two vasa deferentia that end into a single ejaculatory duct (Fig. 1A). Each vas deferens, before reaching the ejaculatory duct, presents a discrete dilation that corresponds to the seminal vesicle. The ejaculatory duct ends in a rudimentary copulatory organ, the penis, which protrudes through the genital pore, located in the intersegmental membrane between the 9th and the 10th abdominal sternites.

A pair of lobed testicles are located laterally to the digestive tube, in the dorsal region of the abdomen, in all individuals. The testicular lobes, vasa deferentia and seminal vesicles are very similar in size and development in fifth-instar nymphs (Fig. 1B) and alates. In neotenic kings and in primary kings from field colonies, testicle development is more conspicuous (Fig. 1C and D), occupying the whole abdomen in primary kings. The testicular lobes of all males are composed of a set of seminiferous tubules, which are joined together by a surrounding capsule, the peritoneal sheath. Spermatogenesis occurs inside the seminiferous tubules that are 


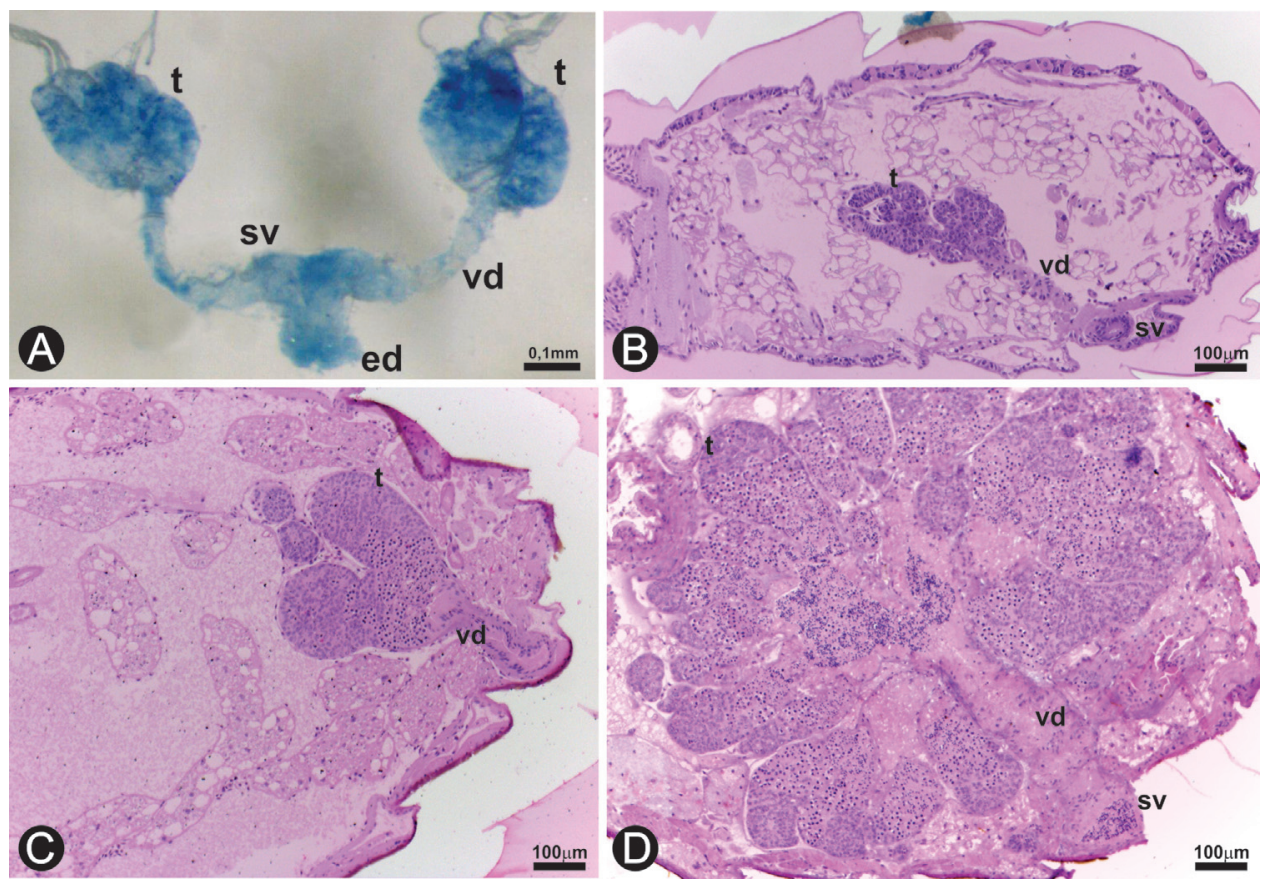

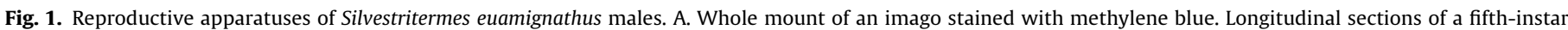
nymph (B), a neotenic king (C) and a primary king (D) stained with hematoxylin-eosin. ed, ejaculatory duct; vd, vas deferens; t, testicular lobes; sv, seminal vesicle.

enclosed by this sheath, a region where somatic and germ cells are present (Fig. 2).

The number of testicular lobes is difficult to evaluate in nymphs and alates, because the testicles are not well developed in these individuals and their tubules are still compacted (Fig. 2A-F). Despite that, it is possible to observe the seminiferous tubules being uncompressing as the nymphal instars evolve (Fig. 2A-E). The three functional reproductives of $S$. euamignathus show differences in the development of their reproductive apparatus when compared to one another (Fig. 2G-I). The histology of testicular lobes of fourmonth old kings is similar to that observed in the alates (Fig. 2G); however, in primary kings (Fig. $2 \mathrm{H}$ ) and in neotenic kings from field colonies (Fig. 2I), the lobes are perfectly separated, larger, and shaped like fingers, with a minimum of seven lobes (up to ten are observed) in the former.

Each testicular lobe, from the top to the base, is formed by a series of zones in which the germinative cells are arranged in groups, or cysts, that are in progressive stages of development, from spermatogonium to spermatozoon, and are separated from each other by the peritoneal sheath. Additionally, in each cyst, all germinative cells are at the same stage of development, and they differ according to the phase of the male life cycle (Fig. 2). The different phases of spermatogenesis occur in the testicular cysts of thirdinstar nymphs and older, including alates, primary and neotenic kings (Fig. 2C-I). The large-sized lobes allow better observation of the spermatogenesis phases and of the spermatozoa in primary and neotenic kings from field colonies (Fig. $2 \mathrm{H}$ and I, respectively). The apical region of the seminiferous tubules in male reproductives shows a mass of small, irregular, and generally, flattened cells. This region frequently presents cells in division and is largely connected to trachea (Fig. 2F). Below this apical region, there are cells of a similar developmental stage with rounded nuclei, which are easily observed in neotenic reproductives (Fig. 2I). The basal region of seminiferous tubules presents cells with typical features of meiotic chromatin as well as spermatozoa (Fig. $2 \mathrm{H}$ ). The spermatozoa of $S$. euamignathus are rounded, lack flagella and are $2-3 \mu \mathrm{m}$ in diameter.
Table 1

Mean \pm S.E. of the testicular area (in $\mu \mathrm{m}^{2}$ ) in the male reproductives of Silvestritermes euamignathus. Different letters mean statistical differences.

\begin{tabular}{ll}
\hline Individual & Testicular Area \\
\hline Nymph 1 & $5097.7 \pm 486 \mathrm{a}$ \\
Nymph 2 & $7829.1 \pm 660.7 \mathrm{~b}$ \\
Nymph 3 & $7915.2 \pm 566 \mathrm{~b}$ \\
Nymph 4 & $9580.8 \pm 584.3 \mathrm{bc}$ \\
Nymph 5 & $11342.1 \pm 1448.2 \mathrm{bc}$ \\
Alates & $13402.9 \pm 839.4 \mathrm{c}$ \\
Neotenic king & $27365.3 \pm 1197.3 \mathrm{~d}$ \\
Primary king from field colony & $75693.02 \pm 1822.9 \mathrm{e}$ \\
\hline
\end{tabular}

The testicles of $S$. euamignathus have a significant increase in size after males reach maturity $(\mathrm{F}=189.7 ; \mathrm{df}=7,40 ; P<0.001)$, and this may be observed following the development of these organs in nymphs of different instars (Fig. 2A-E) by comparing it with alates and kings (Fig. 2F-I). The comparative measurements are shown in Table 1. The differentiation of seminiferous tubules begins in third-instar nymphs, which already present early differentiation of the cells in the cysts, whereas only spermatogonia can be found in first- and second-instar nymphs (Figs. 2A and 2B). The testicles of fourth- and fifth-instar nymphs show many cysts with cells in different phases of spermatogenesis, principally the fifth-instar nymphs (Fig. 2D and E). These fifth-instar nymphs have already completed spermatogenesis, as spermatozoa are found inside some cysts, though in small quantities (Fig. 2E). In addition to the enlargement of the testicles, the whole reproductive system of S. euamignathus increases in size from first-instar to fifth-instar nymphs (Fig. 2A-E).

The vasa deferentia are paired and leave the testicles, migrating laterally towards the base of the 9th sternite, joining together in the ejaculatory duct. In alates, the corresponding tubes are composed of a simple columnar epithelial tissue surrounded by an external muscle layer and measure approximately $571.9 \pm 59.88 \mu \mathrm{m}$ in length and $70 \pm 12.5 \mu \mathrm{m}$ in width. 


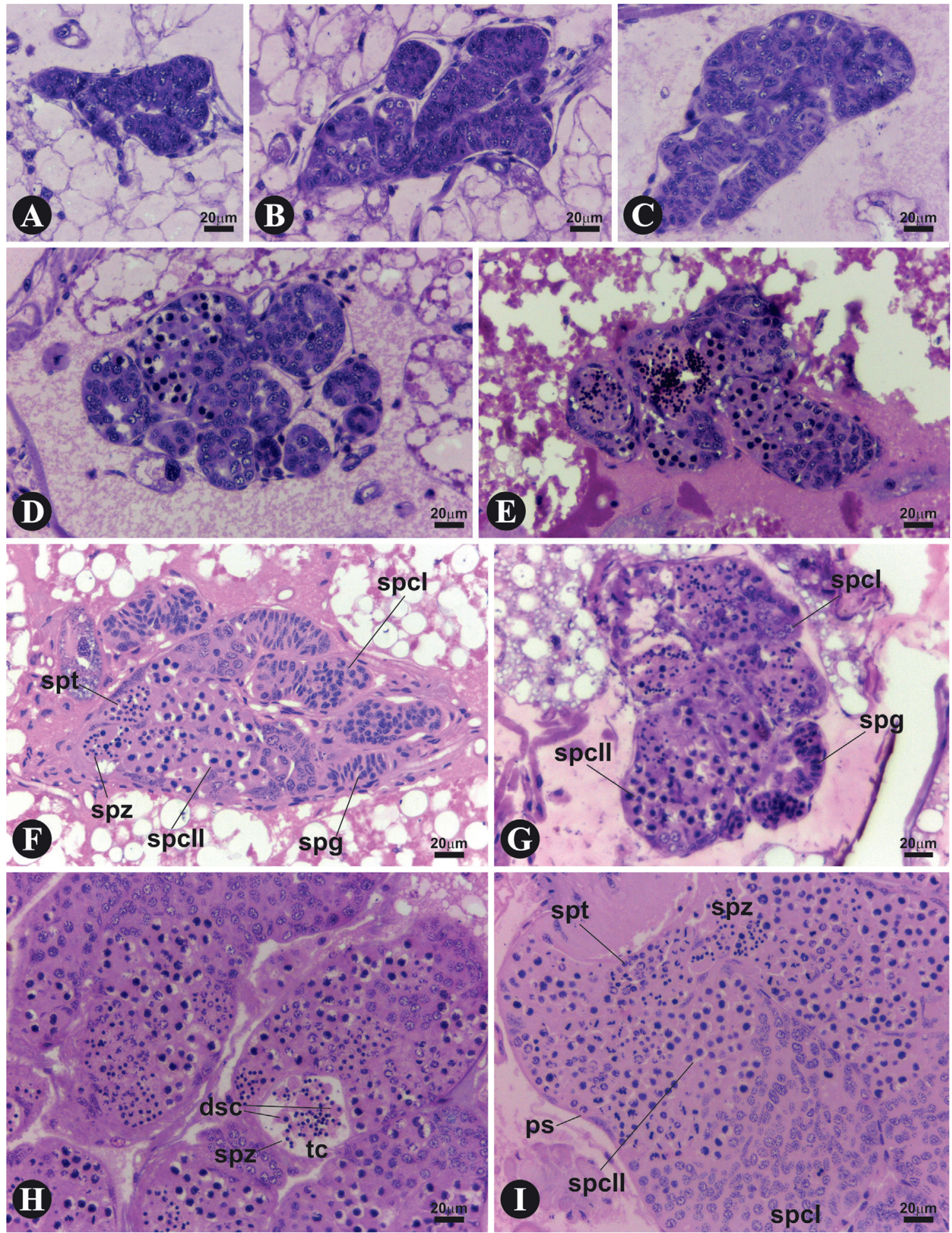

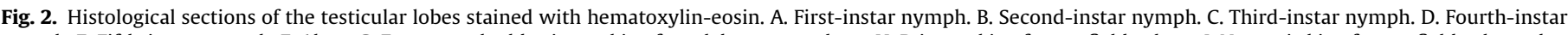

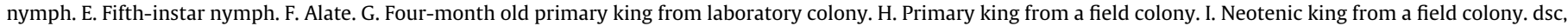
degenerative sex cells; ps, peritoneal sheath; spg, spermatogonia; spcI, spermatocyte I; spcII, spermatocyte II; spt, spermatid; spz, spermatozoa, tc, terminal chamber.

The seminal vesicles appear as dilations of the vasa deferentia in their distal portion (Fig. 3). In alates, they measure around $173 \pm 50.06 \mu \mathrm{m}$ in length and $114.5 \pm 31.45 \mu \mathrm{m}$ in width. The vesicles are lined with a simple epithelium with a brush border, enveloped externally by musculature, and this pattern is found in seminal vesicles from nymphs to older kings. The variable parameters are the number of spermatozoa found inside those structures and the shape of the cells in the different portions of the seminal vesicles. The seminal vesicles in first- to fourth-instar nymphs are in an early developmental stage and still exhibit an empty and small lumen (Fig. 3A). Fifth-instar nymphs, despite having seminal vesicles with very small lumens when compared to imagos, already have some spermatozoa scattered in their lumen (Fig. 3B). Only a few spermatozoa are observed in fifth-instar nymphs, and 

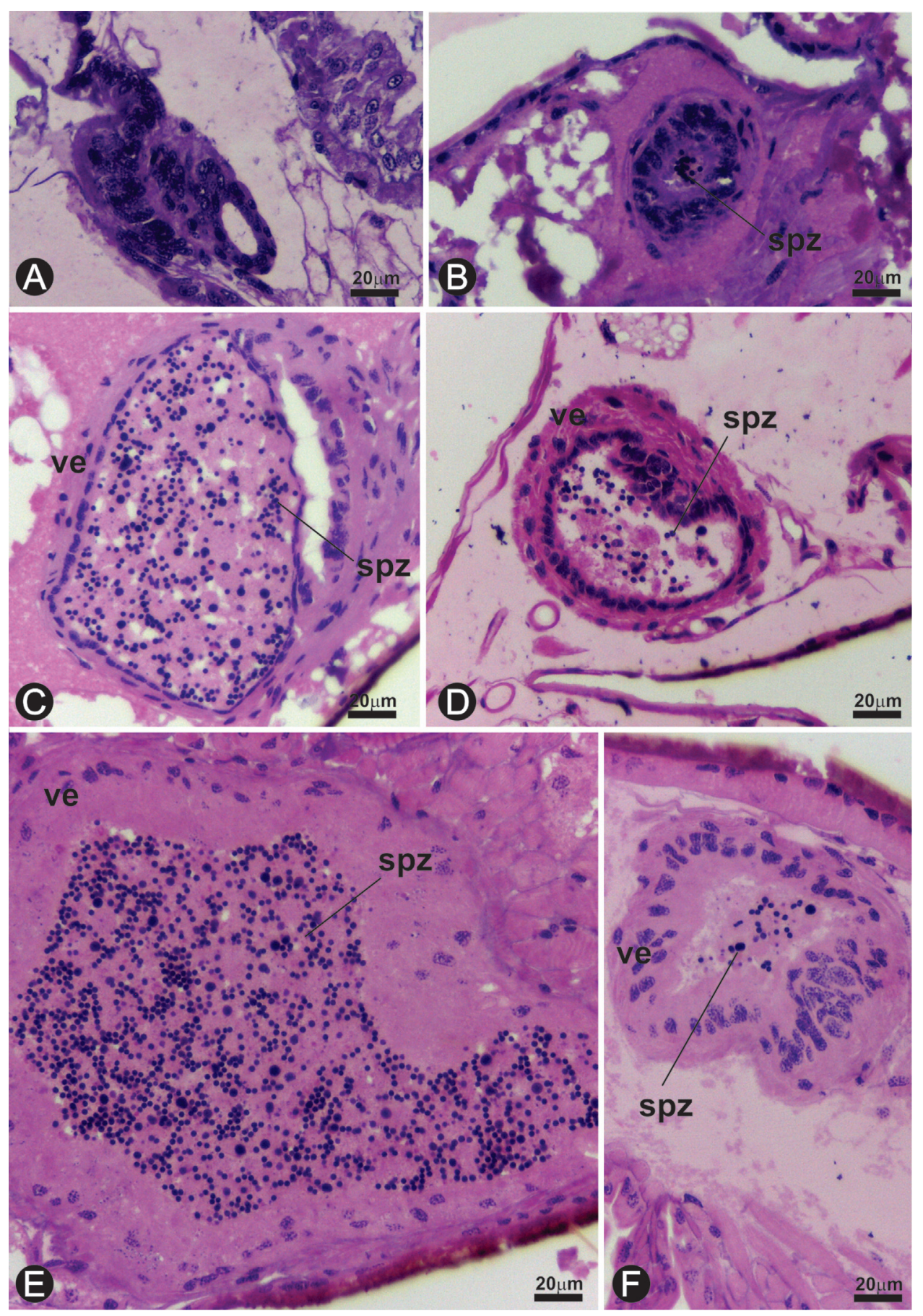

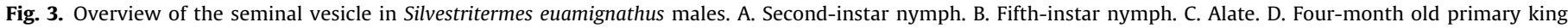
(laboratory colony). E. Primary king from a field colony. F. Neotenic king from a field colony. Dye: hematoxylin-eosin.; spz, spermatozoa; ve, vesicular epithelium.

they increase in number in alates and functional kings from field colonies, but are also low in four-month old kings (Fig. 3C-E). Neotenic kings show a smaller number of spermatozoa when compared to functional kings from field colonies (Fig. 3E and F).

There was no reaction to the test for polysaccharide detection (PAS) in the lumen of seminal vesicles in any of the reproductives, which suggests that the secretion from that structure contains no neutral polysaccharides. Additionally, xylidine Ponceau histochemical test shows a proteinaceous secretion that is present in seminal vesicles of alates (Fig. 4A), but it disappears in primary four-month old kings and neotenic reproductives. The last two reproductives show only spermatozoa and degenerative sex cells in the lumen of their seminal vesicles (Fig. 4B and C).

The ejaculatory duct shows a single layer of epithelial cells, which is externally surrounded by a muscle layer (Fig. 5A and B). The ejaculatory duct is formed by the junction of the vasa deferentia in a median duct, and it ends in a membranous penis. The penis in S. euamignathus reproductives is a retractile organ, small in size and formed by the final portion of the ejaculatory duct (Fig. 5C and D).

The ultrastructure of a cyst containing spermatocytes I is shown in Fig. 6A. These spermatocytes show several mitochondria in 

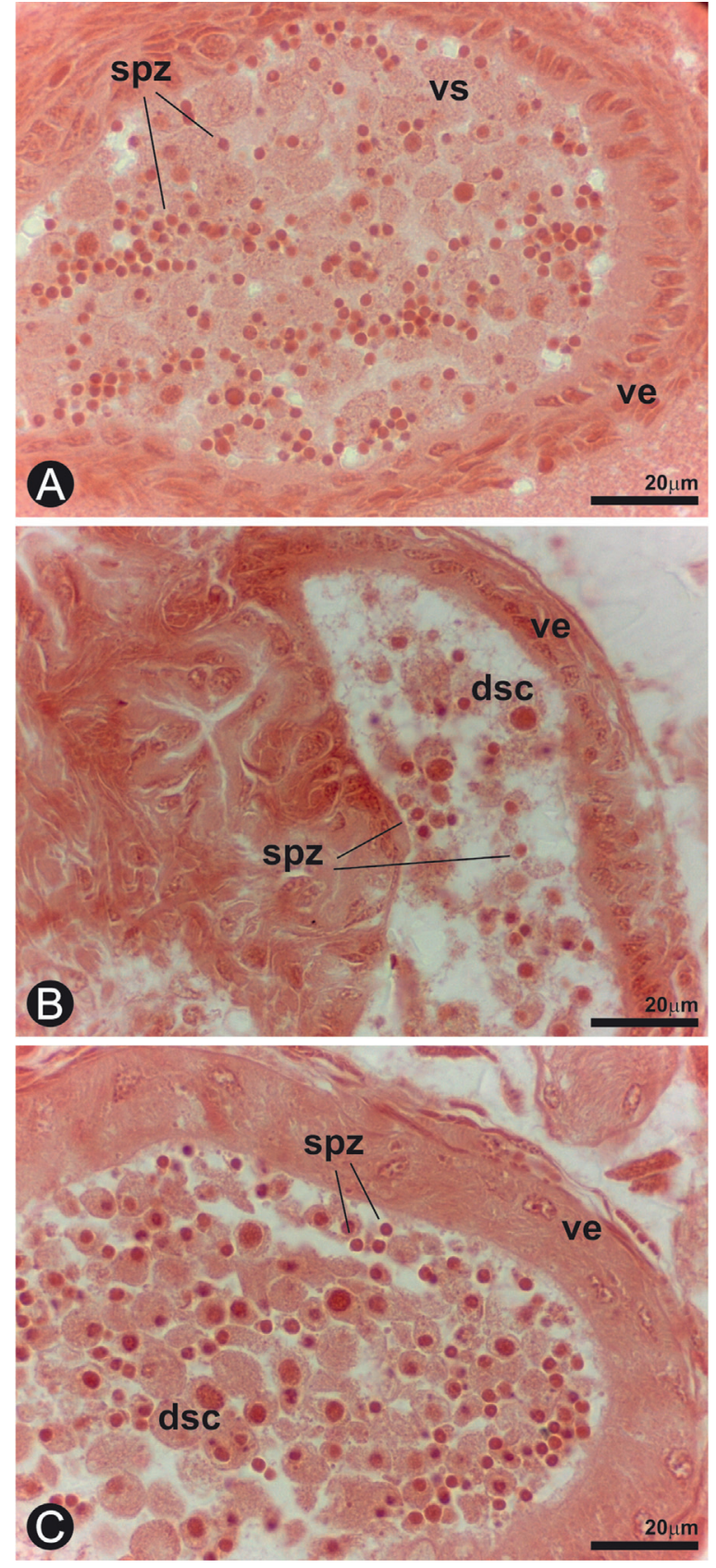

Fig. 4. Seminal vesicles in Silvestritermes euamignathus males. A. Alate. B. Fourmonth old primary king (laboratory colony). C. Neotenic king from a field colony. Dye: XP. dsc, degenerative sex cells; spz, spermatozoa; ve, vesicular epithelium; vs, vesicular secretion.

the apical pole, many free ribosomes scattered in the cytoplasm and multi-lamellar structures similar to lysosomes (Fig. 6B). An overview of the seminal vesicle shows the simple epithelium enveloped in a thick visceral musculature (Fig. 6C). Additionally, the vesicular epithelial cells present nuclear envelopes with an irregular surface, and septate junctions adhering adjacent cells (Fig. 6D and $\mathrm{E}$ ). The lumen of seminal vesicles of alates shows spermatozoa and degenerative sex cells of testicular origin (Fig. 6F). The spermatozoa are spherical, strongly electron-dense and may have electron-lucent regions in their nuclei, which are also spherical (Fig. 6F). The degenerative sex cells are larger than the spermatozoa, and they always have electron-dense nuclei surrounded by electron-lucent regions (Fig. 6F).

\section{Discussion}

The male reproductive system of functional reproductives in termites is comparable to that found in hymenopterans (Alford, 1975; Hölldobler and Bartz, 1985; Hölldobler and Wilson, 1990; Duvoisin et al., 1999; Baer, 2005), and in other insects (Simmons, 2001). It is formed by a pair of testicles, connected to a vas deferens, that join together to form the ejaculatory duct. The seminal vesicles in S. euamignathus are dilations of the final portion of the vasa deferentia and differ from those individualized structures described for some lower termites (Grassé, 1982).

In termites, the testicles are formed by lobes in which the spermatozoa are produced. In kings of S. euamignathus, each testicle presented at least seven testicular lobes, a number similar to that found in imagos of other species of the family Termitidae, such as Termes saltans alates with 6-10 testicular lobes (Godoy and Torales, 2000), Tenuirostritermes tenuirostris young kings with 6-8 lobes (Weesner, 1955) and Cubitermes fungifaber alates with 4-12 lobes (N'diaye, 1977).

The maturation of the testicles seems to be precocious in $S$. euamignathus, because third-instar nymphs already exhibit differentiated cells in their testicular lobes. Following post-embryonic development, the reproductive system presents a progressive development in size and number of spermatozoa produced, reaching a peak of development in old primary kings from field colonies. The testicular lobes of primary and neotenic kings of $S$. euamignathus were completely separate from each other, as occurs in dipterans and some orthopterans, in which the testicles consist of individual structures that are connected to the vas deferens (Chapman, 1998). Based on the analysis of intestinal contents during the maturation of kings of Macrotermes michaelseni, Sieber and Leuthold (1982) suggested that males go through a change in food habits that could influence the growth of their testicles until they hypertrophy, in the case of mature colonies. During the establishment of the colony, the reproductives feed by themselves; while in mature colonies, they receive saliva from workers, which contributes to the enlargement of the king's gonads.

According to the pioneering study by Weesner (1969), the apical portion of termite testicular lobes shows spermatogonia, the middle portion spermatocytes I and the basal region spermatocytes II. Spermatocytes II give rise to the spermatids, which will differentiate into spermatozoa. The ultrastructure of the testicular lobes of $S$. euamignathus showed that spermatocytes I are characterized by a great quantity of multivesicular and multi-lamellar electron-dense bodies, in addition to many mitochondrial clusters. These characteristics were also observed in Kalotermes flavicollis by Grandi (1992), and are considered as specialized structures closely related to a specific stage of cellular differentiation.

When completely differentiated, the spermatozoa of $S$. euamignathus are rounded and aflagellated. Aflagellated spermatozoa are commonly observed in all Termitidae, and most lower termites, including K. flavicollis, Reticulitermes lucifugus (Baccetti et al., 1974) and Coptotermes formosanus (Raina et al., 2007). To date, the most remarkable difference in spermatozoa morphology was recorded for the basal termite Mastotermes darwiniensis, in which the spermatozoa are mobile and present approximately 100 flagella (Baccetti and Dallai, 1978; Dallai, 2014; Dallai et al., 2016).

The spermatozoa differentiated in the testicles are transported, via vasa deferentia, to the seminal vesicles. In S. euamignathus, the seminal vesicles store sperm and are only dilations of the basal portion of the vasa deferentia. Functional kings from field colonies presented more developed seminal vesicles, with a higher number of spermatozoa in their lumen than alates. Our results show that the secretion from the seminal vesicles is proteinaceous in alates of S. euamignathus, but it was not observed in primary and neotenic kings. Probably, this alteration in the secretion of the vesi- 


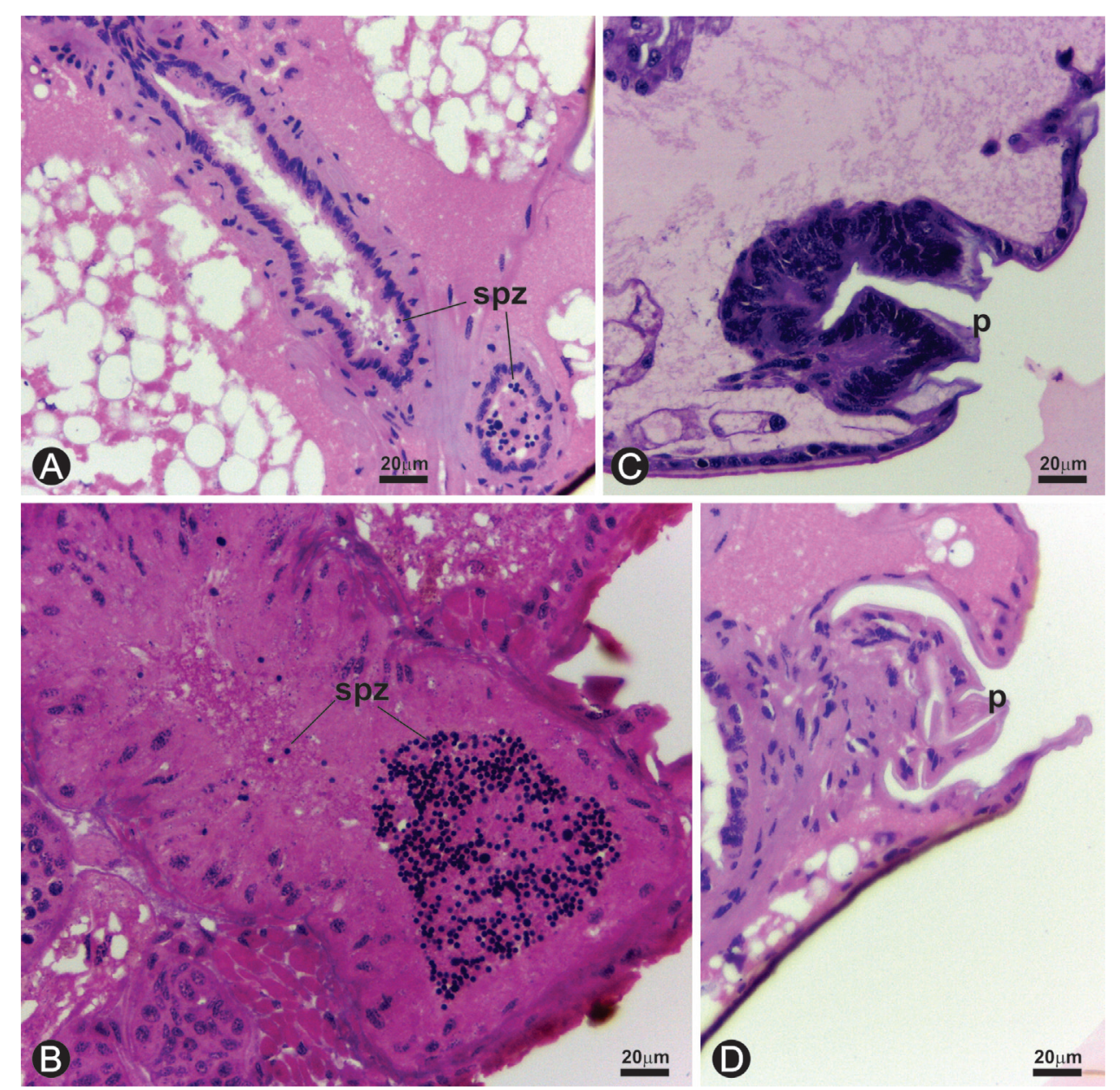

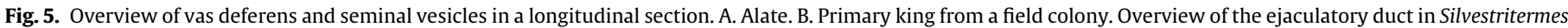
euamignathus males. C. Nymph. D. Alate. Dye: hematoxylin-eosin. p, penis; spz, spermatozoa.

cles is related to the maturation of the kings, which will release the sperm in a short time. This corroborates the idea that seminal vesicles are also important during the pre-reproductive period, because they produce a proteinaceous secretion that may nourish the spermatozoa.

The main functions of the male reproductive system are the production and storage of spermatozoa, and their transportation in a viable state to the reproductive system of a female. In $S$. euamignathus, spermatozoa are produced in the testicles and stored in seminal vesicles that are structures closely related to the ejaculatory duct, which ends in a retractile penis. This retractile penis is similar in structure to that described for the termite $C$. fungifaber (N'diaye, 1977).

Similar to the hymenopterans, termite colonies are founded after alate swarming (Nutting, 1969). However, while in majority of social hymenopterans newly-inseminated females found new colonies themselves, termites start a new colony with a royal couple, the king and the queen, known as primary reproductives. These reproductives remain together inside the colony, and mate several times during their lives (Nutting, 1969; Sieber and Leuthold, 1982). Termite colonies show oviposition cycles during the life of the reproductives (Raina et al., 2003), and these cycles might also be related to male reproductive status. Our results showed that fourmonth old kings from laboratory colonies were probably in a period of reproductive inactivity, because they showed fewer sperm in seminal vesicles when compared to alates.

Over the next few years of colony development, the queen becomes physogastric through a series of important alterations, including the growth of the reproductive system and modifications of fat body (Bordereau, 1982; Godoy and Torales, 1994; CostaLeonardo et al., 2013). The modifications that termite males go through from the mating flight to maturity are less marked, and the currently available studies are scarce and incomplete, mainly pertaining to neotenic kings. In S. euamignathus, as neotenic kings may originate from different nymphal instars (Costa-Leonardo et al., 1999; Haifig and Costa-Leonardo, 2016), their reproductive system is less developed than that present in functional primary kings. Neotenic kings are numerous in the colony and these multiple individuals may supply the necessary quantity of sperm for colony reproduction similar to a single, primary king.

In sum, the maturation of the male reproductive system was followed during post-embryonic development in the imaginal line of the termite S. euamignathus. The testicles are small in firstinstar nymphs, but increases in size and cellular differentiation were observed after third-instar nymphs, with fully-developed spermatozoa in fifth-instar nymphs. The fact that these developed spermatozoa are found in fifth-instar nymphs might be related to the capacity of these individuals to differentiate into alates or into neotenic kings when necessary, supplementing or, as has being widely recorded for this species, replacing the primary king (CostaLeonardo et al., 1998; Haifig et al., 2016). Conversely, the great development of the reproductive system observed in the kings from field colonies is consistent with their participation in colony reproduction. In these individuals, the seminal vesicles appear morphologically as an additional structure and are completely full of spermatozoa for the regular insemination of the queen. The dynam- 

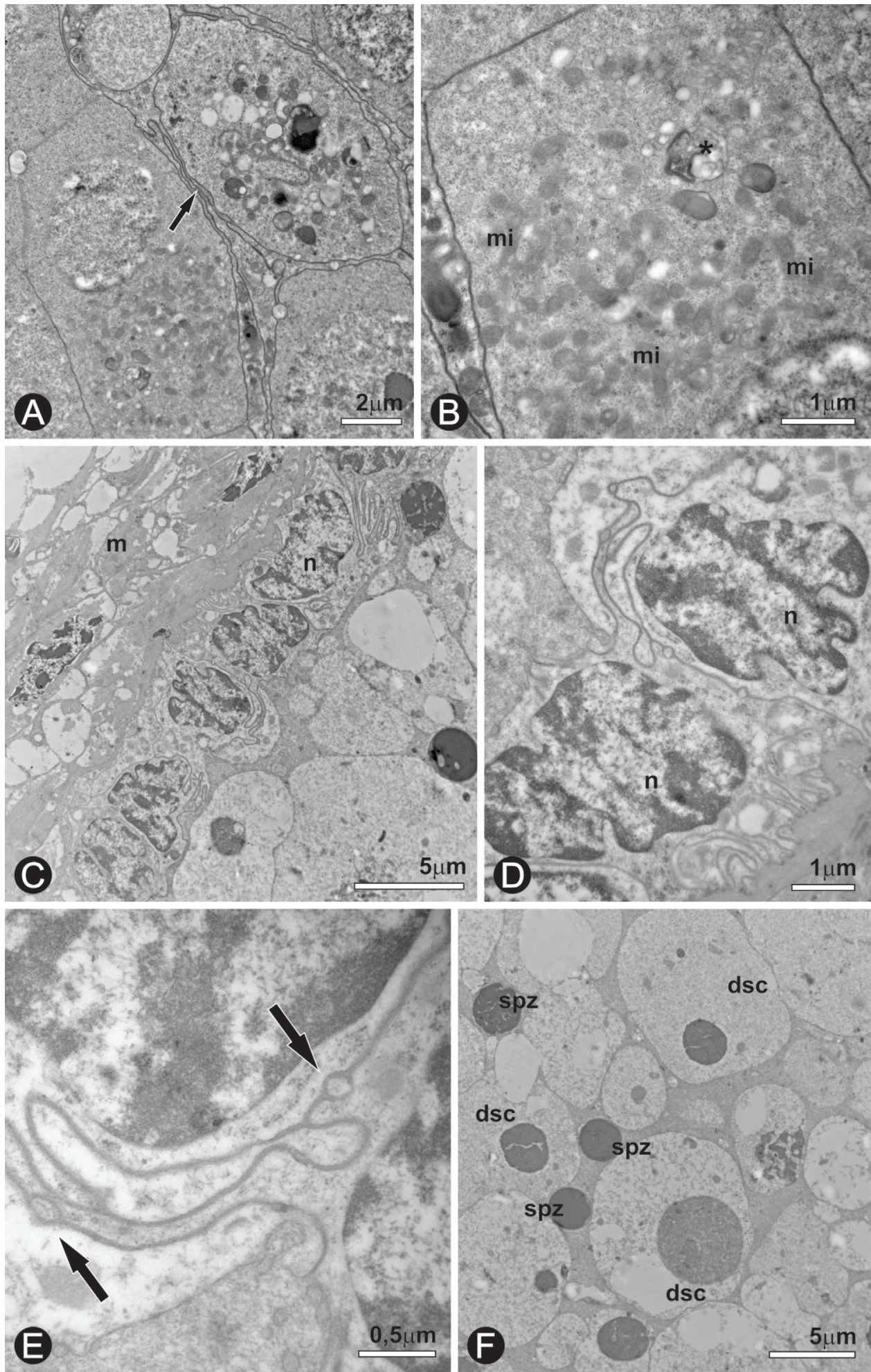

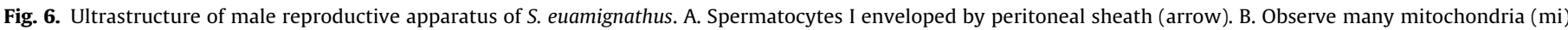

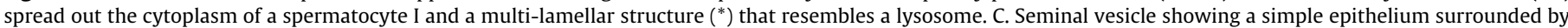

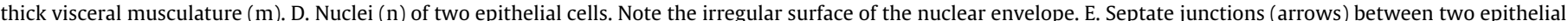
cells. F. Lumen of seminal vesicle with degenerative sex cells (dsc) and spermatozoa (spz).

ics in the proteinaceous secretion of the seminal vesicles observed within the reproductives throughout the maturation of termite males, from later nymphal instars to primary and neotenic kings from field colonies, might be related to the periods of storage and release of spermatozoa, which reflect the functional or non- functional reproductive status of the individual at a particular age. Consistently, our study indicates that the male reproductive system in S. euamignathus is also subjected to differentiation that might parallel physogastry in the queen throughout the years, but in more discreet proportions. 


\section{Acknowledgements}

The authors thank FAPESP (Proc. No. 2011/10590-4) and CNPq (Proc. No. 305539/2014-0) for financial support.

\section{References}

Alford, D.V., 1975. Bumblebees. Davis-Poynter, London.

Araújo, R.L., 1958. Contribuição à biogeografia dos térmitas de São Paulo, Brasil. Insecta-Isoptera. Arq. Inst. Biol. 25, 185-217.

Baccetti, B., Dallai, R., 1978. The spermatozoon of Arthropoda XXX. The multiflagellate spermatozoon in the termite Mastotermes darwiniensis. J. Cell Biol. 76, 569-576.

Baccetti, B., Dallai, R., Rosati, F., Giusti, F., Bernini, F., Selmi, G., 1974. The spermatozoon of Arthropoda. XXVI. The spermatozoon of Isoptera, Embioptera and Dermaptera. J. Microsc. 21, 159-172.

Baer, B., 2005. Sexual selection in Apis bees. Apidologie 36, 187-200.

Bordereau, C., 1982. Ultrastrucuture of the fat body of the reproductive pair in higher termites. J. Morph. 172 (3), 313-322.

Chapman, R.F., 1998. The insects. Structure and function. Cambridge University Press, Cambridge.

Constantino, R., 2017. On-line Termite Database (Accessed 16 Feb 2017) URL http://164.41.140.9/catal/.

Costa-Leonardo, A.M., Barsotti, R.C., Soares, H.X., 1996. Multiple nymphoid reproductives in the nests of the Neotropical termite, Armitermes euamignathus (Isoptera, Termitidae, Nasutitermitinae). Sociobiology 28 (2), 197-205.

Costa-Leonardo, A.M., Barsotti, R.C., 1998. Amputação antenal e aspectos da revoada do cupim Coptotermes havilandi (Isoptera, Rhinotermitidae) na cidade de Rio Claro. In: XVII Congresso Brasilerio de Entomologia, Rio de Janeiro, RJ. Resumos do XVII Congresso Brasileiro de Entomologia, Rio de Janeiro, RJ, v. 2. p. 1010.

Costa-Leonardo, A.M., Barsotti, R.C., Soares, H.X., 1999. Morphology of the nymphoid replacement reproductives in the Neotropical termite Armitermes euamignathus (Isoptera, Termitidae, Nasutitermitinae). J. Morph. 239 (2), 131-141.

Costa-Leonardo, A.M., Laranjo, L.T., Janei, V., Haifig, I., 2013. The fat body of termites: Functions and stored materials. J. Insect Physiol. (2013), 577-587.

Crawley, M.J., 2007. The R Book. J. Wiley, Chichester.

Dallai, R., 2014. Overview on spermatogenesis and sperm structure of Hexapoda. Arthropod Struct Develop 43, 257-290.

Dallai, R., Gottardo, M., Beutel, R.G., 2016. Structure and evolution of insect sperm: new interpretations in the age of phylogenomics. Annu Rev. Entomol. 61, 1-23.

Dean, S., Gold, R., 2004. Sex ratios and development of the reproductive system in castes of Reticulitermes flavipes (Kollar) (Isoptera: Rhinotermitidae). Ann. Entomol. Soc. Am. 97, 147-152.

Domingos, D.J., 1985. Densidade e distribuição espacial de ninhos de duas espécies de Armitermes (Isoptera, Termitidae) em cinco formações vegetais de cerrado. Rev. Bras. Biol. 45 (3), 233-240.

Duvoisin, N., Baer, B., Schmid-Hempel, P., 1999. Sperm transfer and male competition in a bumblebee. Anim Behav. 58, 743-749.

Fougeyrollas, R., Dolejšová, K., Sillam-Dussès, D., Roy, V., Poteaux, C., Hanus, R., Roisin, Y., 2015. Asexual queen succession in the higher termite Embiratermes neotenicus. Proc. R. Soc. B Biol. Sci. 282, 20150260.

Fougeyrollas, R., Krivánek, J., Roy, V., Dolejsová, K., Frechault, S., Roisin, Y., Hanus, R., Sillam-Dussès, D., 2017. Asexual queen succession mediates an accelerated colony life cycle in the termite Silvestritermes minutus. Mol. Ecol., http://dx.doi. org/10.1111/mec.14095.

Fournier, D., Hellemans, S., Hanus, R., Roisin, Y., 2016. Facultative asexual reproduction and genetic diversity of populations in the humivorous termite Cavitermes tuberosus. Proc. R. Soc. B Biol. Sci. 283, 20160196.

Godoy, M.C., Torales, G.J., 1994. Aportes al conocimiento del sistema reproductor de imagos y reinas de Termitidae Neotropicales (Isoptera: Nasutitermitinae y Termitinae). Pap Avulsos Zool. 39 (2), 3-27.

Godoy, M.C., Torales, G.J., 2000. Reproductive system of young male imagoes and kings of Termes saltans (Isoptera, Termitidae). Sociobiology 35 (1), 141-148.

Grandi, G., 1992. Ultrastructural study of testis development and spermatogenesis in Kalotermes flavicollis (Fabr.) (Isoptera, Kalotermitidae). Boll. Zool. 59, 225-238.

Grassé, P.P., 1982. Termitologia. Tome I. Masson, Paris.

Haifig, I., Costa-Leonardo, A.M., 2016. Caste differentiation pathways in the Neotropical termite Silvestritermes euamignathus (Isoptera: Termitidae) Entomol. Sci. 19, 174-179.
Haifig, I., Vargo, E.L., Labadie, P., Costa-Leonardo, A.M., 2016. Unrelated secondary reproductives in the neotropical termite Silvestritermes euamignathus (Isoptera: Termitidae). Naturwissenschaften 103 (9), 1-8.

Hartke, T.R., Baer, B., 2011. The mating biology of termites: a comparative review. Anim Behav. 82 (5), 927-936.

Hayashi, Y., Lo, N., Miyata, H., Kitade, O., 2007. Sex-linked genetic influence on caste determination in a termite. Science 318, 985-987.

Hellemans, S., Fournier, D., Hanus, R., Roisin, Y., 2017. Secondary queens in the parthenogenetic termite Cavitermes tuberosus develop through a transitional helper stage. Evol Dev. 19, 253-262.

Hölldobler, B., Bartz, S.H., 1985. Sociobiology of reproduction in ants. In: Hölldobler, B., Lindauer, M. (Eds.), Experimental Behavioural Ecology and Sociobiology. Gustav Fischer Verlag, Stuttgart, pp. 237-257.

Hölldobler, B., Wilson, E.O., 1990. The Ants. Springer Verlag, Berlin.

Kitade, O., Hoshi, M., Odaira, S., Asano, A., Shimizu, M., Hayashi, Y., Lo, N., 2011. Evidence for genetically influenced caste determination in phylogenetically diverse species of the termite genus Reticulitermes. Biol Lett. 7, 257-260.

Krishna, K., Grimaldi, D.A., Krishna, V., Engel, M.S., 2013. Treatise on the Isoptera of the world. Bull. Am. Mus. Nat. Hist. 377, 2704.

Luchetti, A., Dedeine, F., Velonà, A., Mantovani, B., 2013. Extreme genetic mixing within colonies of the wood-dwelling termite Kalotermes flavicollis (Isoptera, Kalotermitidae). Mol. Ecol. 22, 3391-3402.

Mao, L., Henderson, G., 2007. A case for a free-running circannual rhythm in soldier developmental time of Formosan subterranean termites. Insectes Soc. 54, 388-392.

Mathews, A.G.A., 1977. Studies on termites from the Mato Grosso State Brazil. Academia Brasileira de Ciências, Rio de Janeiro.

Matsuura, K., 2017. Evolution of the asexual queen succession system and its underlying mechanisms in termites. J. Exp. Biol. 220, 63-72.

Matsuura, K., Vargo, E.L., Kawatsu, K., Labadie, P.E., Nakano, H., Yashiro, T., Tsuji, K. 2009. Queen succession through asexual reproduction in termites. Science 323, 1687.

Myles, T.G., 1999. Review of secondary reproduction in termites (Insecta: Isoptera) with comments on its role in termite ecology and social evolution. Sociobiology 33 (1), 1-91.

N'diaye, M.S., 1977. Le développement post-embryonnaire de l'appareil genital chez les sexués de Cubitermes fungifaber (Sjostedt) (Termitidae, Termitinae). Insectes Soc. 24 (1), 37-60.

Noirot, C., 1956. Les sexués of remplacement chez les termites supérieurs (Termitidae). Insectes Soc. 3, 145-158.

Noirot, C., 1969. Glands and Secretions. In: Krishna, K., Weesner, F. (Eds.), Biology of the Termites, vol. 1. Academic Press, New York, pp. 89-123.

Nutting, W.L., 1969. Flight and colony foundation. In: Krishna, K., Weesner, F. (Eds.), Biology of the Termites, vol. 1. Academic Press, New York, pp. 233-282.

R Core Team, 2016. R: A language and environment for statistical computing. $\mathrm{R}$ Foundation for Statistical Computing, Vienna, Austria (Accessed 21 Jun 2016.) URL https://www.R-project.org/.

Raina, A., Park, Y.I., Florane, C., 2003. Behavior and reproductive biology of the primary reproductives of the Formosan subterranean termite (Isoptera: Rhinotermitidae). Sociobiology 41 (1), 37-48.

Raina, A., Murphy, C., Florane, C., Williams, K., Yong, P., Ingber, B., 2007. Structure of spermatheca, sperm dynamics, and associated bacteria in Formosan subterranean termite (Isoptera: Rhinotermitidae). Ann. Entomol. Soc. Am. 100, $418-424$

Roisin, Y., 2000. Diversity and evolution of caste patterns. In: Abe, T., Bignell, D.E., Higashi, M. (Eds.), Termites: Evolution, sociality, symbioses, ecology. Kluwer Academic Press, London, pp. 95-119.

Sieber, R., Leuthold, R.H., 1982. Repeated copulation and testes enlargement in Macrotermes michaelseni. Physiol. Entomol. 7, 457-465.

Simmons, L.W., 2001. Sperm Competition and its Evolutionary Consequences in the Insects. Princeton University Press, Oxford.

Vargo, E.L., Labadie, P.E., Matsuura, K., 2012. Asexual queen succession in the subterranean termite Reticulitermes virginicus. Proc. R. Soc. B. Biol. Sci. 279, 813-819.

Weesner, F.M., 1955. The reproductive systems of young primary reproductives of Tenuirostritermes tenuirostris (Desneux). Insectes Soc. 2 (4), 323-345.

Weesner, F.M., 1969. External anatomy. In: Krishna, K., Weesner, F.M. (Eds.), Biology of termites, vol. 1. Academic Press, NewYork, pp. 19-47.

Ye, Y., Jones, S.C., Ammar, E., 2009. Reproductive characteristics of imagos of Reticulitermes flavipes (Isoptera: Rhinotermitidae). Ann. Entomol. Soc. Am. 102, 889-894. 